Prepared in cooperation with the Indiana Office of Community and Rural Affairs

\title{
Flood-Inundation Maps for Sugar Creek at Crawfordsville, Indiana
}

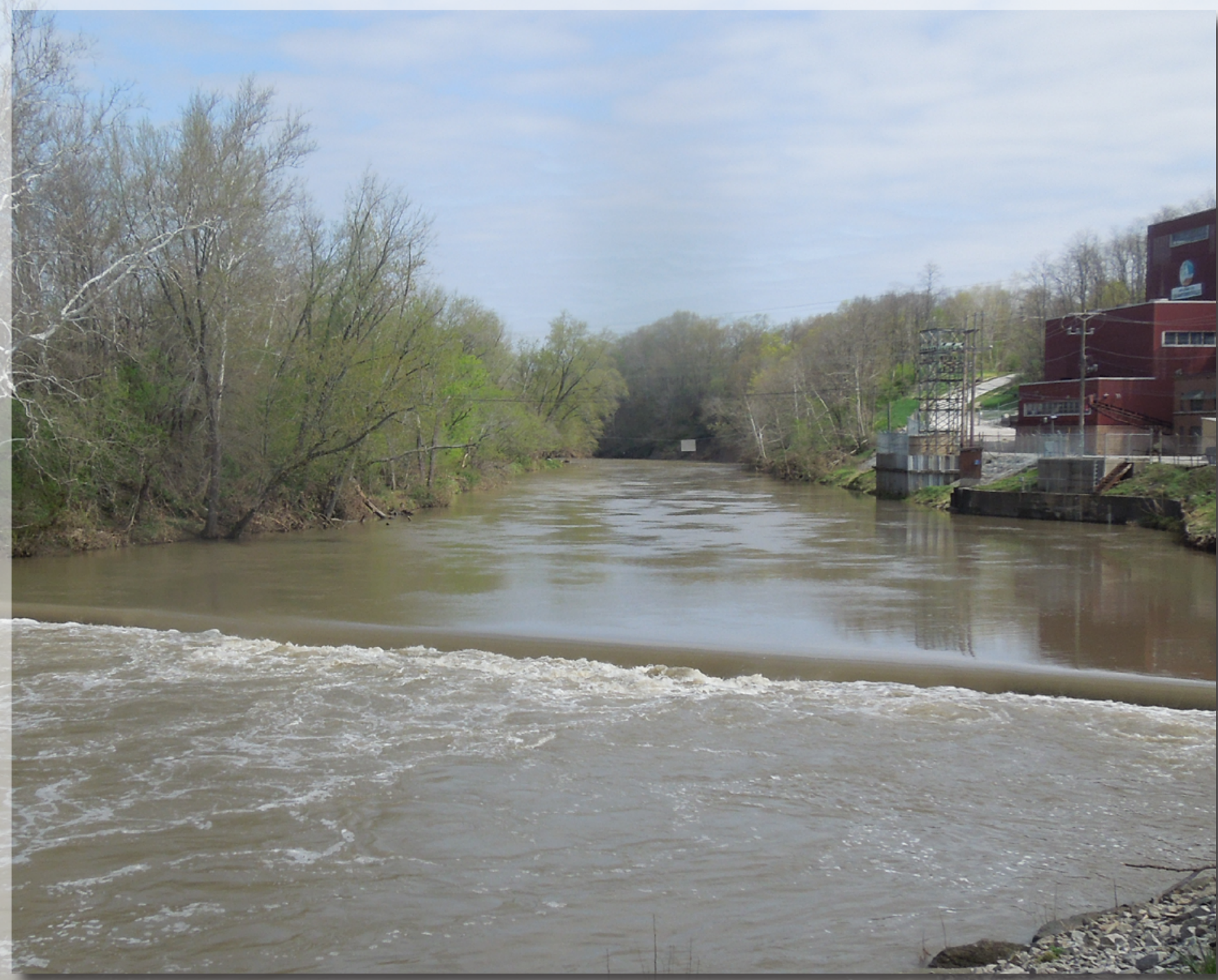

Scientific Investigations Report 2016-5043

U.S. Department of the Interior U.S. Geological Survey 
Cover. Photograph taken by U.S. Geological Survey hydrographer Jeffrey Sallas during a routine field visit of Sugar Creek at Crawfordsville, Indiana, April 2013. 


\section{Flood-Inundation Maps for Sugar Creek at Crawfordsville, Indiana}

By Zachary W. Martin

Prepared in cooperation with the Indiana Office of Community and Rural Affairs

Scientific Investigations Report 2016-5043 


\section{U.S. Department of the Interior SALLY JEWELL, Secretary}

\section{U.S. Geological Survey Suzette M. Kimball, Director}

\section{U.S. Geological Survey, Reston, Virginia: 2016}

For more information on the USGS - the Federal source for science about the Earth, its natural and living resources, natural hazards, and the environment-visit http://www.usgs.gov or call 1-888-ASK-USGS.

For an overview of USGS information products, including maps, imagery, and publications, visit http://store.usgs.gov.

Any use of trade, firm, or product names is for descriptive purposes only and does not imply endorsement by the U.S. Government.

Although this information product, for the most part, is in the public domain, it also may contain copyrighted materials as noted in the text. Permission to reproduce copyrighted items must be secured from the copyright owner.

Suggested citation:

Martin, Z.W., 2016, Flood-inundation maps for Sugar Creek at Crawfordsville, Indiana: U.S. Geological Survey Scientific Investigations Report 2016-5043, 11 p., http://dx.doi.org/10.3133/sir20165043.

ISSN 2328-0328 (online) 


\section{Acknowledgments}

The author wishes to thank the Indiana Department of Transportation for cooperation in funding the operation and maintenance of the gage used for this study. Special thanks are given to the National Weather Service for their continued support of the U.S. Geological Survey floodinundation mapping program. 



\section{Contents}

Acknowledgments ……...................................................................................................................

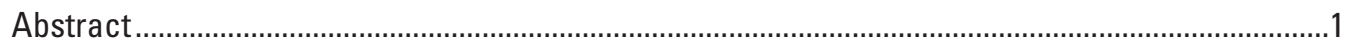

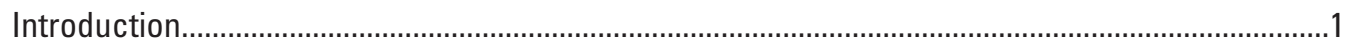

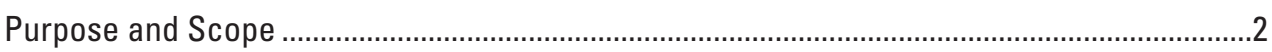

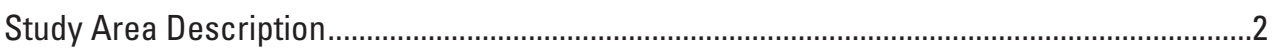

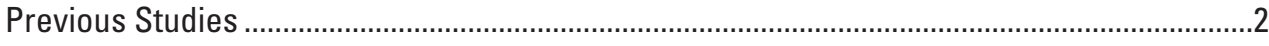

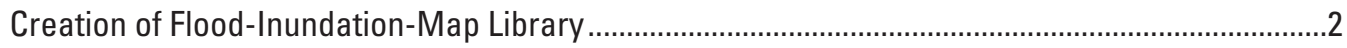

Computation of Water-Surface Profiles.................................................................................

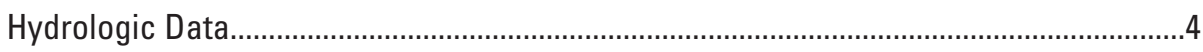

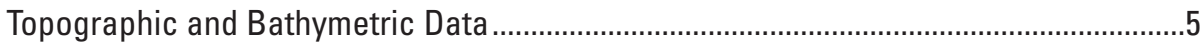

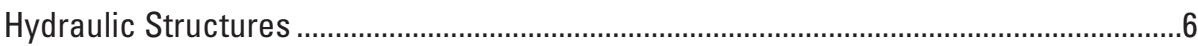

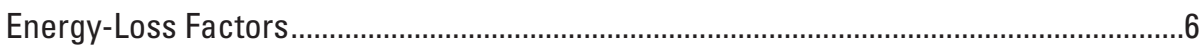

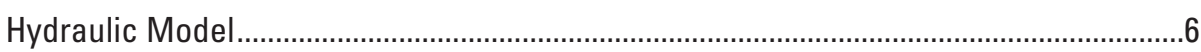

Development of Water-Surface Profiles ...........................................................................

Development of Flood-Inundation Maps ……………........................................................

Flood-Inundation Map Delivery ....................................................................................

Disclaimer for Flood-Inundation Maps ............................................................................

Uncertainties and Limitations Regarding Use of Flood-Inundation Maps ......................8

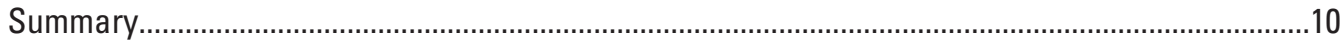

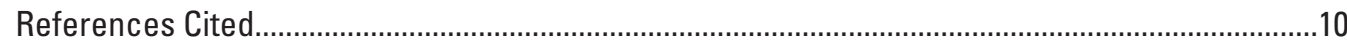

\section{Figures}

1. Map showing location of study reach for Sugar Creek at Crawfordsville, Indiana, and location of U.S. Geological Survey streamgage 03339500.

2. Map showing flood-inundation map for Sugar Creek at Crawfordsville, Indiana, corresponding to a stage of 16.0 feet at the U.S. Geological Survey streamgage 03339500

\section{Tables}

1. U.S. Geological Survey streamgage information for Sugar Creek at Crawfordsville, Indiana....

2. Coordinated discharges for selected annual exceedance probabilities for Sugar Creek at Crawfordsville, Indiana .

3. Estimated discharges for corresponding stages and water-surface elevations at selected locations, used in the hydraulic model of U.S. Geological Survey streamgage 03339500, Sugar Creek at Crawfordsville, Indiana.

4. Calibration of hydraulic model to target water-surface elevations at U.S. Geological Survey streamgage 03339500, Sugar Creek at Crawfordsville, Indiana

5. Calibration of hydraulic model to high-water mark elevations at selected locations along Sugar Creek for the flood of April 19, 2013 


\section{Conversion Factors}

Inch/Pound to SI

\begin{tabular}{lcl}
\hline \multicolumn{1}{c}{ Multiply } & By & \multicolumn{1}{c}{ To obtain } \\
\hline foot $(\mathrm{ft})$ & Length & meter $(\mathrm{m})$ \\
mile $(\mathrm{mi})$ & 0.3048 & kilometer $(\mathrm{km})$ \\
\hline & 1.609 & \\
\hline square ${\mathrm{mile}\left(\mathrm{mi}^{2}\right)}$ & Area & square kilometer $\left(\mathrm{km}^{2}\right)$ \\
\hline & 2.590 & \\
\hline cubic foot per second $\left(\mathrm{ft}^{3} / \mathrm{s}\right)$ & Flow rate & cubic meter per second $\left(\mathrm{m}^{3} / \mathrm{s}\right)$ \\
\hline
\end{tabular}

Vertical coordinate information is referenced to (1) stage, the height above an arbitrary datum established at a streamgage, and (2) elevation, the height above the North American Vertical Datum of 1988 (NAVD 88).

Horizontal coordinate information is referenced to the North American Datum of 1983 (NAD 83). 


\title{
Flood-Inundation Maps for Sugar Creek at Crawfordsville, Indiana
}

\author{
By Zachary W. Martin
}

\section{Abstract}

Digital flood-inundation maps for a 6.5-mile reach of Sugar Creek at Crawfordsville, Indiana, were created by the U.S. Geological Survey (USGS) in cooperation with the Indiana Office of Community and Rural Affairs. The floodinundation maps, which can be accessed through the USGS Flood Inundation Mapping Science Web site at http://water. usgs.gov/osw/flood_inundation/, depict estimates of the areal extent and depth of flooding corresponding to selected water levels (stages) at the USGS streamgage 03339500, Sugar Creek at Crawfordsville, Ind. Near-real-time stages at this streamgage may be obtained on the Internet from the USGS National Water Information System at http://waterdata.usgs. gov/ or the National Weather Service (NWS) Advanced Hydrologic Prediction Service at http:/water.weather.gov/ ahps/, which also forecasts flood hydrographs at this site (NWS site CRWI3).

Flood profiles were computed for the USGS streamgage 03339500, Sugar Creek at Crawfordsville, Ind., reach by means of a one-dimensional step-backwater hydraulic modeling software developed by the U.S. Army Corps of Engineers. The hydraulic model was calibrated using the current stage-discharge rating at the USGS streamgage 03339500, Sugar Creek at Crawfordsville, Ind., and highwater marks from the flood of April 19, 2013, which reached a stage of 15.3 feet. The hydraulic model was then used to compute 13 water-surface profiles for flood stages at 1-foot (ft) intervals referenced to the streamgage datum ranging from $4.0 \mathrm{ft}$ (the NWS "action stage") to $16.0 \mathrm{ft}$, which is the highest stage interval of the current USGS stage-discharge rating curve and $2 \mathrm{ft}$ higher than the NWS "major flood stage." The simulated water-surface profiles were then combined with a Geographic Information System digital elevation model (derived from light detection and ranging [lidar]) data having a $0.49-\mathrm{ft}$ root mean squared error and 4.9-ft horizontal resolution) to delineate the area flooded at each stage.

The availability of these maps, along with Internet information regarding current stage from the USGS streamgage and forecasted high-flow stages from the NWS, will provide emergency management personnel and residents with information that is critical for flood response activities such as evacuations and road closures, as well as for post-flood recovery efforts.

\section{Introduction}

The city of Crawfordsville, Indiana, located in central Montgomery County along the banks of Sugar Creek, has an estimated population of 15,915 (U.S. Census Bureau, 2010). Crawfordsville and surrounding communities have experienced flooding numerous times, most recently in 2002, 2009, and 2013. The highest documented flood on Sugar Creek was in March 1913 and reached a stage corresponding to 17.3 feet (Peak Streamflow, U.S. Geological Survey, 2015a). Sugar Creek flows through Montgomery County from the Northeast to the Southwest. The Sugar Creek floodplain near Crawfordsville is used mostly for agricultural and recreational purposes. At various stages, and for National Weather Service (NWS) Flood Categories, recreational, agricultural, residential, and commercial areas are affected by the floodwaters of Sugar Creek (National Weather Service, 2015a).

Prior to this study, emergency responders in Crawfordsville relied on several information sources to make decisions on how to best alert the public and mitigate flood damages. One source is the Federal Emergency Management Agency (FEMA) flood insurance study (FIS) for Montgomery County, dated February 2, 2012 (Federal Emergency Management Agency, 2012). A second source of information is the U.S. Geological Survey (USGS) streamgage 03339500, Sugar Creek at Crawfordsville, Ind., from which current (U.S. Geological Survey, 2015a) and historic (since 1913; U.S. Geological Survey, 2015b) stages and discharges, including annual peak flows, can be obtained (http://nwis.waterdata.usgs.gov/ in/nwis/uv/?site_no $=03339500 \&$ agency_cd=USGS). A third source of flood-related information is the NWS Advanced Hydrologic Prediction Service (AHPS), which displays the current USGS stage data and issues forecasts of stage for USGS streamgage 03339500, Sugar Creek at Crawfordsville, Ind., (National Weather Service, 2015a). The NWS does not routinely issue forecasts for the Sugar Creek at Crawfordsville, Indiana, streamgage, but does so as needed during times of high-stage flows, (National Weather Service, 2015a).

Although the current stage at a USGS streamgage is particularly useful for residents in the immediate vicinity of a streamgage, it is of limited use to residents farther upstream or downstream because the water-surface elevation is not constant along the entire stream reach. Knowledge of 
the water level at a streamgage is difficult to translate into depth and areal extent of flooding at points distant from the streamgage. One way to address these informational gaps is to produce a library of flood-inundation maps that are referenced to the stages recorded at the USGS streamgage. By referring to the appropriate map, emergency responders can discern the severity of flooding (depth of water and areal extent), identify roads that are or will soon be flooded, and make plans for notification or evacuation of residents in harm's way for some distance upstream and downstream from the streamgage. In addition, the capability to visualize the potential extent of flooding has been shown to motivate residents to take precautions and heed warnings that they previously might have disregarded. In 2014-15, the USGS, in cooperation with the Indiana Office of Community and Rural Affairs, conducted a project to produce a library of flood-inundation maps for Sugar Creek at Crawfordsville, Ind.

\section{Purpose and Scope}

This report describes the development of a series of estimated flood-inundation maps for Sugar Creek at Crawfordsville, Ind., at selected stages referenced to USGS streamgage 03339500, and identifies where on the Internet the maps can be found and ancillary data (Geographic Information System [GIS] flood polygons and depth grids) can be downloaded. The flood-inundation maps correspond to stages at USGS streamgage 03339500 , and the NWS forecasted stages at the NWS site CRWI3. The location of the study covers a 6.5 -mile (mi) reach along Sugar Creek, from 2.4 mi upstream of the streamgage, where it intersects U.S. Interstate 74 , to $4.1 \mathrm{mi}$ downstream of the streamgage, approximately $0.5 \mathrm{mi}$ downstream of County Road N225W (fig. 1).

The maps were produced for flood levels referenced to the stage recorded at USGS streamgage 03339500, Sugar Creek at Crawfordsville, Ind. (table 1); the gage is on the east bank of Sugar Creek 0.1 mi upstream of U.S. Highway 231. The maps cover a range in stage from 4.0 to 16.0 feet (ft), above gage datum. The 4.0-ft stage is near bankfull and is defined by the National Weather Service (2015b) as the "action stage" or the stage which, when reached by a rising stream, requires the NWS or a partner to take some type of mitigation action in preparation for possible significant hydrologic activity. The 16.0-ft stage is the highest interval stage on the current USGS stage-discharge rating curve. The 14.0-ft stage is the "major stage," as determined by the NWS (2015b).

\section{Study Area Description}

The Sugar Creek study reach is adjacent to the city of Crawfordsville, which is in northwest-central Indiana and the county seat of Montgomery County. The stream is in the Tipton Till Plain physiographic section of the Central Till Plain Region (Gray, 2000). Sugar Creek's headwaters originate near the Boone and Hamilton County line (not shown) and flow east to west until entering the Wabash River north of Montezuma, Ind. (not shown). The drainage area at the upstream end of the study reach is 414 square miles $\left(\mathrm{mi}^{2}\right)$, at the USGS streamgage is $509 \mathrm{mi}^{2}$, and at the downstream end of the study reach is $523 \mathrm{mi}^{2}$ (U.S. Geological Survey, 2015a, 2015d). The study reach is approximately $6.5 \mathrm{mi}$ long and has an approximate channel slope of 0.0009 ( 4.8 feet per mile $[\mathrm{ft} / \mathrm{mi}])$. The main tributary in the study reach for Sugar Creek is Walnut Fork Sugar Creek, which is about 1 mi upstream of the streamgage. The primary land use along the study reach is agricultural and recreational with a few residential and commercial areas. The study reach is traversed by one railroad bridge, two state highway bridges, and three local bridges. A broad-crested, concrete, low-head dam (as shown in the cover image) is just downstream of the streamgage.

\section{Previous Studies}

The current FIS for Montgomery County was completed by United Consulting Engineers and Architects, on behalf of the Indiana Department of Natural Resources in 2006 (Federal Emergency Management Agency, 2012). The Sugar Creek near Crawfordsville portion of the FIS was a floodway redelineation Hydrologic Engineering Centers-2 (HEC-2) model computed by the Louisville District of the U.S. Army Corps of Engineers for the Indiana Department of Natural Resources (U.S. Army Corps of Engineers, undated). The extents of the FIS model for Sugar Creek in Montgomery County are $33.8 \mathrm{mi}$ above the confluence with the Wabash River to $43.2 \mathrm{mi}$ above the confluence with the Wabash River (U.S. Army Corps of Engineers, undated).

The FIS presents estimates of the coordinated peak discharges of 10- and 1-percent annual exceedance probabilities (table 2) for Sugar Creek at Crawfordsville, Ind., and Sugar Creek above Walnut Fork Sugar Creek (Federal Emergency Management Agency, 2012). Coordinated peak discharge frequency values are agreed upon by the Indiana Department of Natural Resources, the USGS, the Natural Resource Conservation Service, and the U.S. Army Corps of Engineers for select streams to maintain consistency in flood frequency values in the state of Indiana (Indiana Department of Natural Resources, 2014). In addition, to the referenced source, the coordinated discharge values can be obtained on StreamStats (http://streamstats.usgs.gov/indiana.html; U.S. Geological Survey, 2015d).

\section{Creation of Flood-Inundation-Map Library}

The USGS has standardized the procedures for creating flood-inundation maps for flood-prone communities (U.S. Geological Survey, 2015c) so that the process and products are consistent regardless of which USGS office is responsible for 

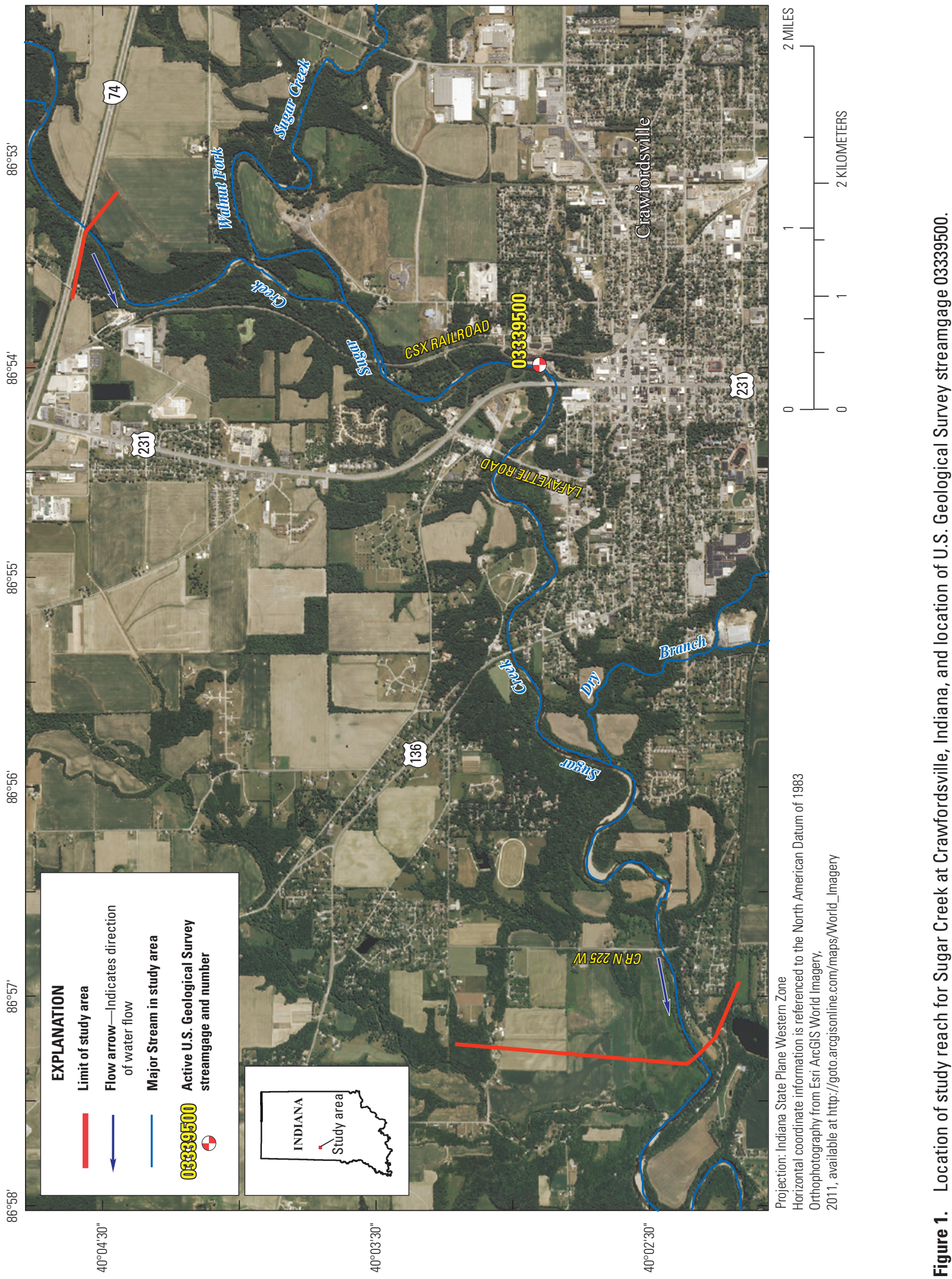
Table 1. U.S. Geological Survey streamgage information for Sugar Creek at Crawfordsville, Indiana.

[Station location is shown in figure $1 . \mathrm{mi}^{2}$, square miles; ', degree; ', minutes; ", seconds; $\mathrm{ft}$, feet; $\mathrm{ft}^{3} / \mathrm{s}$, cubic feet per second; NAVD 88, North American Vertical Datum of 1988]

\begin{tabular}{|c|c|c|c|c|c|c|c|c|}
\hline Station name & $\begin{array}{l}\text { Station } \\
\text { number }\end{array}$ & $\begin{array}{l}\text { Drain- } \\
\text { age area } \\
\left(\mathrm{mi}^{2}\right)\end{array}$ & Latitude & Longitude & $\begin{array}{c}\text { Datum of } \\
\text { gage } \\
\text { (ft, NAVD 88) }\end{array}$ & Period of record & $\begin{array}{l}\text { Maximum } \\
\text { stage (ft) } \\
\text { and date }\end{array}$ & $\begin{array}{c}\text { Maximum } \\
\text { discharge } \\
\left(\mathrm{ft}^{3} / \mathrm{s}\right) \text { and date }\end{array}$ \\
\hline $\begin{array}{l}\text { Sugar Creek at } \\
\text { Crawfordsville, } \\
\text { Ind. }\end{array}$ & 03339500 & 509 & $40^{\circ} 02^{\prime} 56^{\prime \prime}$ & $86^{\circ} 53^{\prime} 58^{\prime \prime}$ & 657.34 & $\begin{array}{l}\text { June } 1938 \text { to cur- } \\
\text { rent year (2015) }\end{array}$ & $\begin{array}{l}{ }^{1} 17.3, \\
\quad \text { March } 1913\end{array}$ & $\begin{array}{l}236,000, \\
\text { March } 1913\end{array}$ \\
\hline
\end{tabular}

${ }^{1}$ Stage was documented from information by a local resident.

${ }^{2}$ Estimated value.

the work. Tasks specific to development of the flood maps for Crawfordsville, Ind., were: (1) operation of the Crawfordsville streamgage and collection of streamflow data on Sugar Creek (table 1), (2) collection of topographic and bathymetric data for selected cross sections and geometric data for structures and bridges along the study reach, (3) estimation of energyloss factors (roughness coefficients) in the stream channel and flood plain and determination of steady-flow data,

(4) computation of water-surface profiles using the U.S. Army Corps of Engineers' Hydrologic Engineering Centers River Analysis System (HEC-RAS) computer program (U.S. Army Corps of Engineers, 2010a, b), (5) production of estimated flood-inundation maps at various stream stages using the U.S. Army Corps of Engineers' Hydrologic Engineering Centers Geospatial River Analysis System (HEC-GeoRAS) computer program (U.S. Army Corps of Engineers, 2011) and a Geographic Information System (GIS), and (6) preparation of the maps, both as shapefile polygons that depict the areal extent of flood inundation and as depth grids that provide the depth of floodwaters, for display on a USGS flood-inundation mapping application.

\section{Computation of Water-Surface Profiles}

The water-surface profiles used to produce the 13 flood-inundation maps in this study were computed using
HEC-RAS, version 4.1.0 (U.S. Army Corps of Engineers, 2010a, b). HEC-RAS is a one-dimensional step-backwater model for simulation of water-surface profiles with steadystate (gradually varied) or unsteady-state flow computation options.

\section{Hydrologic Data}

The study reach includes USGS streamgage 03339500 , Sugar Creek at Crawfordsville, Ind., (fig. 1; table 1), which has been in operation since June 1938. Water level (stage) is measured every 15 minutes, transmitted hourly by a satellite antenna at the streamgage, and made available on the Internet through the USGS National Water Information System (NWIS; U.S. Geological Survey, 2015b). Stage data from this streamgage are referenced to a local datum but can be converted to water-surface elevations referenced to the North American Vertical Datum of 1988 (NAVD 88) by adding $657.34 \mathrm{ft}$. Continuous records of streamflow are computed from a stage-discharge relation, which has been developed for the streamgage, and are available through the USGS NWIS Web site (http://waterdata.usgs.gov/nwis).

The flows used in the model simulations (table 3) were taken from the current stage-discharge relation for streamgage 03339500 (number 20.1, effective April 19, 2013) and corresponded with the target stages. Two tributaries-Walnut Fork Sugar Creek and Dry Branch—-join Sugar Creek within

Table 2. Coordinated discharges for selected annual exceedance probabilities for Sugar Creek at Crawfordsville, Indiana.

[Data from Federal Emergency Management Agency (2012). $\mathrm{mi}^{2}$, square miles; $\mathrm{ft}^{3} / \mathrm{s}$, cubic feet per second; USGS, U.S. Geological Survey]

\begin{tabular}{lccc}
\hline \multirow{2}{*}{ Location on Sugar Creek } & $\begin{array}{c}\text { Drainage area } \\
\left(\mathbf{m i}^{2}\right)\end{array}$ & \multicolumn{2}{c}{$\begin{array}{c}\text { Estimated discharges }\left(\mathbf{f t}^{\mathbf{3}} \mathbf{s}\right) \text { for indicated annual exceedance probabilities, } \\
\text { in percent }\end{array}$} \\
\cline { 3 - 4 } & & $\mathbf{1 0}$ & $\mathbf{1}$ \\
\hline Above Walnut Fork Sugar Creek & 415 & 16,400 & 30,000 \\
USGS streamgage 03339500 & 509 & 18,500 & 34,000 \\
\hline
\end{tabular}


Table 3. Estimated discharges for corresponding stages and water-surface elevations at selected locations, used in the hydraulic model of U.S. Geological Survey (USGS) streamgage 03339500, Sugar Creek at Crawfordsville, Indiana.

[ft, feet; NAVD 88, North American Vertical Datum of 1988; $\mathrm{mi}^{2}$, square miles]

\begin{tabular}{|c|c|c|c|c|}
\hline \multirow[b]{2}{*}{$\begin{array}{l}\text { Stage of water- } \\
\text { surface profile } \\
\quad(\mathrm{ft})^{1}\end{array}$} & \multirow[b]{2}{*}{$\begin{array}{l}\text { Water surface } \\
\text { elevation } \\
\text { (ft, NAVD 88) }\end{array}$} & \multicolumn{3}{|c|}{ Estimated discharge at indicated location, in cubic feet per second } \\
\hline & & $\begin{array}{c}\text { At upstream } \\
\text { end of study reach, } \\
\text { drainage area }=414 \mathrm{mi}^{2}\end{array}$ & $\begin{array}{l}\text { USGS streamgage } 03339500 \\
\text { (downstream from Walnut Fork Sugar } \\
\text { Creek), drainage area }=509 \mathrm{mi}^{2}\end{array}$ & $\begin{array}{c}\text { Downstream from confluence } \\
\text { with Dry Branch, } \\
\text { drainage area }=521 \mathrm{mi}^{2}\end{array}$ \\
\hline 4.0 & 661.34 & 2,500 & 2,820 & 2,860 \\
\hline 5.0 & 662.34 & 4,260 & 4,790 & 4,860 \\
\hline 6.0 & 663.34 & 5,970 & 6,730 & 6,820 \\
\hline 7.0 & 664.34 & 7,540 & 8,490 & 8,610 \\
\hline 8.0 & 665.34 & 8,980 & 10,100 & 10,300 \\
\hline 9.0 & 666.34 & 10,300 & 11,600 & 11,800 \\
\hline 10.0 & 667.34 & 11,700 & 13,200 & 13,400 \\
\hline 11.0 & 668.34 & 13,400 & 15,100 & 15,300 \\
\hline 12.0 & 669.34 & 15,500 & 17,500 & 17,700 \\
\hline 13.0 & 670.34 & 18,300 & 20,600 & 20,900 \\
\hline 14.0 & 671.34 & 21,300 & 24,000 & 24,300 \\
\hline 15.0 & 672.34 & 24,800 & 28,000 & 28,400 \\
\hline 16.0 & 673.34 & 28,700 & 32,300 & 32,700 \\
\hline
\end{tabular}

${ }^{1}$ Water-surface profiles are 1-foot increments of stage, referenced to the gage datum of the U.S. Geological Survey streamgage, Sugar Creek at Crawfordsville, Indiana (station number 03339500).

the 6.5-mi study reach. The streamgage-derived discharges were adjusted to account for tributary inflows (table 3). These adjustments were calculated based on the average percent difference in discharge estimates from the coordinated discharge reach at the three locations in table 3, using a Web-based application named StreamStats (http://streamstats.usgs.gov/ indiana.html; U.S. Geological Survey, 2015d). The discharges at the upstream end of the reach were decreased 11.2 percent from the streamgage-rated discharges, and the discharges downstream of Dry Branch were increased 1.4 percent from the streamgage-rated discharges.

\section{Topographic and Bathymetric Data}

All topographic data used in this study are referenced vertically to NAVD 88 and horizontally to the North American Datum of 1983 (NAD 83). Cross-section elevation data were obtained from a digital elevation model (DEM) that was derived from light detection and ranging (lidar) data that were collected as part of a statewide project during 2011-13 by Woolpert, Inc., Geospatial Services, Dayton, Ohio (Woolpert, Inc., 2011). The lidar data for Montgomery County was collected in 2013. The DEM was obtained from the Indiana Spatial Data Portal (Indiana University, 2013). The original lidar data have horizontal resolution of $4.9 \mathrm{ft}$ and vertical accuracy of $0.98 \mathrm{ft}$ at a 95 -percent confidence level based on a root mean squared error of $0.49 \mathrm{ft}$ for the "open terrain" land-cover category. By these criteria, the lidar data support production of 2-ft contours (Dewberry, 2012); the final DEM, which was resampled to a grid-cell size of $10 \mathrm{ft}$ by $10 \mathrm{ft}$ to decrease the GIS processing time, has a vertical accuracy of plus or minus $1 \mathrm{ft}$. HEC-GeoRAS, version 10.2, is a set of procedures, tools, and utilities for processing geospatial data in ArcGIS and was used to extract elevation data from the DEM for 86 cross sections and subsequently input to the HEC-RAS model. The 86 cross section lines were drawn to best represent flow vectors in the channel and floodplain.

Because lidar data cannot provide ground elevations below a stream's water surface, channel cross sections were surveyed by USGS field crews during 2013-14. Crosssectional depths were measured by wading at 38 locations. A differential global positioning system with real-time kinematic technology was used to derive horizontal locations and the elevation of the water-surface at each surveyed cross section. Where possible, DEM-generated cross sections were made to coincide with the locations of the within-channel fieldsurveyed cross sections. In these cases, within-channel data were directly merged with the DEM data. For all other cross sections, the within-channel data were estimated by interpolation from the closest field-surveyed cross section. 
In the ArcMap application of ArcGIS (Esri, 2015), these field data were used in conjunction with a bathymetry mesh tool that was created by Merwade and others (2008) to interpolate below-water ground elevations through the study reach. The density of ground elevations in the mesh was determined by two variables: (1) the number of parallel longitudinal profiles that were evenly spaced across the channel and ran the length of the study reach and (2) the user-specified spacing between cross sections. Ground elevations were either extracted or interpolated from the field data at the intersections of longitudinal profiles and cross sections that were spaced on average $400 \mathrm{ft}$ apart. The mesh elevations were subsequently added to the DEM data of the synthetic cross sections before the data were exported to HEC-RAS. Instructions for the bathymetry mesh tool are presented by Merwade (2011).

\section{Hydraulic Structures}

Seven structures, consisting of five road crossings (U.S. Highway 231, Lafayette Avenue, U.S. Highway 136, and County Road N $225 \mathrm{~W}$ [main and overflow]), a railroad bridge, and a broad-crested concrete low-head dam, have the potential to affect water-surface elevations during floods along the stream. Bridge-geometry and low-head dam-geometry data were obtained from field surveys conducted by personnel from the USGS Indiana-Kentucky Water Science Center. The railroad bridge-geometry data were obtained from the HEC-2 model (U.S. Army Corps of Engineers, undated) that was used for the 2012 FIS (Federal Emergency Management Agency, 2012). Levees were not present in this modeled reach of Sugar Creek.

\section{Energy-Loss Factors}

Hydraulic analyses require the estimation of energy losses that result from frictional resistance exerted by a channel on flow. These energy losses are quantified by the Manning's roughness coefficient (" $n$ " value) (Phillips and Tadayon, 2006). Initial (precalibration) $n$ values were selected on the basis of field observations, high-resolution aerial photographs, and the FIS hydraulic model (Federal Emergency Management Agency, 2012). Initially, an $n$ value of 0.032 was selected for the gravel bed material and minimal channel vegetation. The overbank areas in the effective flow zones consisted of dense tree cover, agricultural plains, and some open recreational spaces, so an $n$ value of $0.060-0.080$ was selected.

As part of the calibration process, the initial $n$ values were adjusted until the differences between simulated and observed water-surface elevations at the USGS streamgage and 26 high-water marks from April 19, 2013, were minimized. In addition, the flow roughness adjustment factors option was used in HEC-RAS to help calibrate the model with observed water-surface elevations. The adjustment factors were based on the roughness effects on the water at various stages. The final model $n$-values were computed by multiplying the initial $n$-value by each of the roughness-coefficient adjustment factors. The final $n$ values were $0.034-0.040$ for the main channel and 0.056-0.102 for the overbank areas modeled in this analysis.

\section{Hydraulic Model}

The HEC-RAS analysis for this study was done by using the steady-state flow computation option. Steady-state flow data consisted of flow regime, boundary conditions, and flows that produced water-surface elevations at the streamgage cross section that matched target water-surface elevations. These target elevations coincided with even 1-ft increments of stage, referenced to the local streamgage datum. Subcritical (tranquil) flow regime was assumed for the simulations. Normal depth, based on an estimated average water-surface slope of 0.001 from survey data collected by USGS personnel, was used as the reach's downstream boundary condition. The flows that were used in the model were discussed in the section "Hydrologic Data."

The HEC-RAS hydraulic model was calibrated to the current stage-discharge relation (USGS rating no. 20.1, April 19, 2013) at USGS streamgage 03339500, Sugar Creek at Crawfordsville, Ind., and high-water marks from the flood of April 19, 2013 (U.S. Geological Survey, 2015a). Model calibration was accomplished by adjusting Manning's $n$ values and channel cross section ineffective flow areas until the results of the hydraulic computations closely agreed with the observed water-surface elevations for given flows. Ineffective flow areas were determined based on heavy vegetation, hydraulic connectivity to the channel, and proximity to the channel. Differences between observed and simulated water-surface elevations for the 13 simulated flows at the USGS streamgage were equal to or less than $\pm 0.46 \mathrm{ft}$ (table 4). Differences between surveyed high-water marks and simulated water-surface elevations in the study reach for the flood of April 19, 2013, were less than $\pm 1.02 \mathrm{ft}$ (table 5). The April 19, 2013, high-water mark data were collected for an event that reached $15.33 \mathrm{ft}$ stage at the USGS streamgage. A few high-water marks were not included in the table due to possible errors in identifying the average water-surface elevation in a confined, high-velocity, and bending portion of the stream. The results demonstrate that the model is capable of simulating accurate water levels over a wide range of flows in the basin. The maximum difference of $\pm 0.46 \mathrm{ft}$ displayed in table 4 provides justification for the 1-ft interval floodinundation maps.

\section{Development of Water-Surface Profiles}

The calibrated hydraulic model was used to generate water-surface profiles for a total of 13 stages at 1.0-ft intervals between $4 \mathrm{ft}$ and $16 \mathrm{ft}$ as referenced to the local datum of USGS streamgage 03339500, Sugar Creek at Crawfordsville, 
Table 4. Calibration of hydraulic model to target water-surface elevations at U.S. Geological Survey streamgage 03339500, Sugar Creek at Crawfordsville, Indiana.

[ft, feet; NAVD 88, North American Vertical Datum of 1988]

\begin{tabular}{cccc}
\hline $\begin{array}{c}\text { Stage of } \\
\text { water-surface } \\
\text { profile } \\
\text { (ft) }\end{array}$ & $\begin{array}{c}\text { Target } \\
\text { water-surface } \\
\text { elevation } \\
\text { (ft, NAVD 88) }\end{array}$ & $\begin{array}{c}\text { Modeled } \\
\text { water-surface } \\
\text { elevation } \\
\text { (ft, NAVD 88) }\end{array}$ & $\begin{array}{c}\text { Difference } \\
\text { in elevation } \\
\text { (ft) }\end{array}$ \\
\hline 4 & 661.34 & 661.64 & 0.30 \\
\hline 5 & 662.34 & 662.79 & 0.45 \\
\hline 6 & 663.34 & 663.79 & 0.45 \\
\hline 7 & 664.34 & 664.80 & 0.46 \\
\hline 8 & 665.34 & 665.72 & 0.38 \\
\hline 9 & 666.34 & 666.53 & 0.19 \\
\hline 10 & 667.34 & 667.35 & 0.01 \\
\hline 11 & 668.34 & 668.07 & -0.27 \\
\hline 12 & 669.34 & 668.97 & -0.37 \\
\hline 13 & 670.34 & 670.06 & -0.28 \\
\hline 14 & 671.34 & 671.05 & -0.29 \\
\hline 15 & 672.34 & 672.16 & -0.18 \\
\hline 16 & 673.34 & 673.28 & -0.06 \\
\hline
\end{tabular}

Ind. These stages correspond to elevations of $661.34 \mathrm{ft}$ and $673.34 \mathrm{ft}$, NAVD 88, respectively. Discharges corresponding to the various stages were obtained from the current stagedischarge relation (USGS rating no. 20.1, April 19, 2013) (table 3) for USGS streamgage 03339500, Sugar Creek at Crawfordsville, Ind. Discharges through the study reach were adjusted for tributary inflows as shown in table 3 and as explained in the "Hydrologic Data" section above.

\section{Development of Flood-Inundation Maps}

Flood-inundation maps were created for a reach of Sugar Creek at Crawfordsville, Ind. The maps were created in a GIS by combining the 13 water-surface profiles and digital elevation model data. The DEM data were derived from the same lidar data described previously in the section "Topographic and Bathymetric Data" and therefore have an estimated vertical accuracy of $\pm 0.5 \mathrm{ft}$. Estimated floodinundation boundaries for each simulated profile were developed with HEC-GeoRAS software (U.S. Army Corps of Engineers, 2009), which allows the preparation of geometric data for import into HEC-RAS and processes simulation results exported from HEC-RAS (U.S. Army Corps of
Engineers, 2010a, b). Shapefile polygons and depth grids of the inundated areas for each profile were modified, as required, in the ArcMap application of ArcGIS (Esri, 2015) to ensure a hydraulically reasonable transition of the flood boundaries between modeled cross sections.

Any inundated areas that were detached from the main channel were examined to identify subsurface hydraulic connections with the main river, such as through culverts under roadways. Where such connections existed, the mapped inundated areas were retained in their respective flood maps; otherwise, the erroneously delineated parts of the flood extent were deleted. The flood-inundation areas are overlaid on high-resolution, geo-referenced, aerial photographs of the study area. Bridge surfaces are displayed as inundated regardless of the actual water-surface elevation in relation to the lowest structural chord of the bridge or the bridge deck. Estimates of water depth can be obtained from the depthgrid data that are included with the presentation of the flood maps on an interactive USGS mapping application described in the following section, "Flood-Inundation Map Delivery." The flood map corresponding to the highest simulated watersurface profile, a stage of $16.0 \mathrm{ft}$, is presented in figure 2 .

\section{Flood-Inundation Map Delivery}

A Flood Inundation Mapping Science Web site (http://wimcloud.usgs.gov/apps/FIM/FloodInundationMapper. html) (U.S. Geological Survey, 2015c) has been established to make USGS flood-inundation study information available to the public. That site links to a mapping application that presents map libraries and provides detailed information on flood extents and depths for modeled sites. The mapping application enables the production of customized flood-inundation maps from the map library for Sugar Creek at Crawfordsville, Ind. A link on this Web site connects to the USGS National Water Information System (U.S. Geological Survey, 2015a), which presents the current stage and streamflow at USGS streamgage 03339500, Sugar Creek at Crawfordsville, Ind., to which the inundation maps are referenced. A second link connects to the NWS AHPS site (National Weather Service, 2015a) so that the user can obtain applicable information on forecasted peak stage. The estimated flood-inundation maps are displayed in sufficient detail so that preparations for flooding and decisions for emergency response can be performed efficiently. Depending on the flood magnitude, roadways are shown as shaded (inundated and likely impassable) or not shaded (dry and passable) to facilitate emergency planning and use. Bridges are shaded - that is, shown as inundated - regardless of the flood magnitude. A shaded building should not be interpreted to mean that the structure is completely submerged; rather that bare earth surfaces in the vicinity of the building are inundated. In these instances, the water depth (as indicated in the mapping application by holding the cursor over an inundated area) near the building would be an estimate of the water level inside the structure, unless flood-proofing measures had been implemented. 
Table 5. Calibration of hydraulic model to high-water mark elevations at selected locations along Sugar Creek for the flood of April 19, 2013.

[HWM, high-water mark; ’, degree; ', minutes; ", seconds; ft, feet; NAVD 88, North American Vertical Datum of 1988]

\begin{tabular}{|c|c|c|c|c|c|}
\hline HWM Point name & Latitude & Longitude & $\begin{array}{c}\text { Surveyed water-surface } \\
\text { elevation } \\
\text { (ft, NAVD 88) }\end{array}$ & $\begin{array}{c}\text { Modeled water-surface } \\
\text { elevation } \\
\text { (ft, NAVD 88) }\end{array}$ & $\begin{array}{l}\text { Difference in elevation } \\
\text { (ft) }\end{array}$ \\
\hline hwy231-1 & $40^{\circ} 02^{\prime} 52.9^{\prime \prime}$ & $86^{\circ} 54^{\prime} 07.2^{\prime \prime}$ & 671.20 & 671.30 & -0.10 \\
\hline hwy231-2 & $40^{\circ} 02^{\prime} 52.8^{\prime \prime}$ & $86^{\circ} 54^{\prime} 07.8^{\prime \prime}$ & 671.30 & 671.30 & 0.00 \\
\hline hwy231-3 & $40^{\circ} 02^{\prime} 52.7^{\prime \prime}$ & $86^{\circ} 54^{\prime} 08.7^{\prime \prime}$ & 670.92 & 671.30 & -0.38 \\
\hline hwy231-4 & $40^{\circ} 02^{\prime} 50.5^{\prime \prime}$ & $86^{\circ} 54^{\prime} 08.5^{\prime \prime}$ & 671.48 & 671.30 & 0.18 \\
\hline hwy231-6 & $40^{\circ} 02^{\prime} 53.6^{\prime \prime}$ & $86^{\circ} 54^{\prime} 03.5^{\prime \prime}$ & 670.91 & 671.93 & -1.02 \\
\hline hwy231-7 & $40^{\circ} 02^{\prime} 54.6^{\prime \prime}$ & $86^{\circ} 54^{\prime} 03.4^{\prime \prime}$ & 672.03 & 671.93 & 0.10 \\
\hline hwy231-8 & $40^{\circ} 02^{\prime} 54.3^{\prime \prime}$ & $86^{\circ} 54^{\prime} 02.4^{\prime \prime}$ & 671.38 & 672.05 & -0.67 \\
\hline hwy231-9 & $40^{\circ} 02^{\prime} 54.6^{\prime \prime}$ & $86^{\circ} 54^{\prime} 02.1^{\prime \prime}$ & 671.91 & 672.13 & -0.22 \\
\hline lafayette- 5 & $40^{\circ} 03^{\prime} 02.2^{\prime \prime}$ & $86^{\circ} 54^{\prime} 22.4^{\prime \prime}$ & 670.30 & 670.08 & 0.22 \\
\hline lafayette- 6 & $40^{\circ} 03^{\prime} 02.2^{\prime \prime}$ & $86^{\circ} 54^{\prime} 24.4^{\prime \prime}$ & 669.93 & 670.08 & -0.16 \\
\hline lafayette-7 & $40^{\circ} 02^{\prime} 59.5^{\prime \prime}$ & $86^{\circ} 54^{\prime} 26.3^{\prime \prime}$ & 669.89 & 670.08 & -0.19 \\
\hline CR225W-1 & $40^{\circ} 02^{\prime} 29.7^{\prime \prime}$ & $86^{\circ} 56^{\prime} 47.2^{\prime \prime}$ & 653.67 & 653.42 & 0.25 \\
\hline CR225W-2 & $40^{\circ} 02^{\prime} 24.9^{\prime \prime}$ & $86^{\circ} 56^{\prime} 47.4^{\prime \prime}$ & 653.30 & 653.42 & -0.12 \\
\hline CR225W-3 & $40^{\circ} 02^{\prime} 24.8^{\prime \prime}$ & $86^{\circ} 56^{\prime} 47.6^{\prime \prime}$ & 653.37 & 653.42 & -0.05 \\
\hline CR225W-4 & $40^{\circ} 02^{\prime} 25.1^{\prime \prime}$ & $86^{\circ} 56^{\prime} 45.3^{\prime \prime}$ & 653.80 & 653.96 & -0.16 \\
\hline CR225W-5 & $40^{\circ} 02^{\prime} 25.7^{\prime \prime}$ & $86^{\circ} 56^{\prime} 45.3^{\prime \prime}$ & 654.00 & 653.96 & 0.04 \\
\hline CR225W-6 & $40^{\circ} 02^{\prime} 26.8^{\prime \prime}$ & $86^{\circ} 56^{\prime} 44.7^{\prime \prime}$ & 653.81 & 654.00 & -0.19 \\
\hline
\end{tabular}

\section{Disclaimer for Flood-Inundation Maps}

The flood-inundation maps should not be used for navigation, regulatory, permitting, or other legal purposes. The USGS provides these maps "as-is" for a quick reference, emergency planning tool but assumes no legal liability or responsibility resulting from the use of this information.

\section{Uncertainties and Limitations Regarding Use of Flood-Inundation Maps}

Although the flood-inundation maps represent the boundaries of inundated areas with a distinct line, some uncertainty is associated with these maps. The flood boundaries shown were estimated on the basis of water stages and streamflows at selected USGS stream gages. Water-surface elevations along the stream reaches were estimated by steady-state hydraulic modeling, assuming unobstructed flow, and using streamflows and hydrologic conditions anticipated at the USGS streamgage(s). The hydraulic model reflects the land-cover characteristics and any bridge, dam, levee, or other hydraulic structures existing as of June 2015. Unique meteorological factors (timing and distribution of precipitation) may cause actual streamflows along the modeled reach to vary from those assumed during a flood, which may lead to deviations in the water-surface elevations and inundation boundaries shown. Additional areas may be flooded due to unanticipated conditions such as changes in the streambed elevation or roughness, 

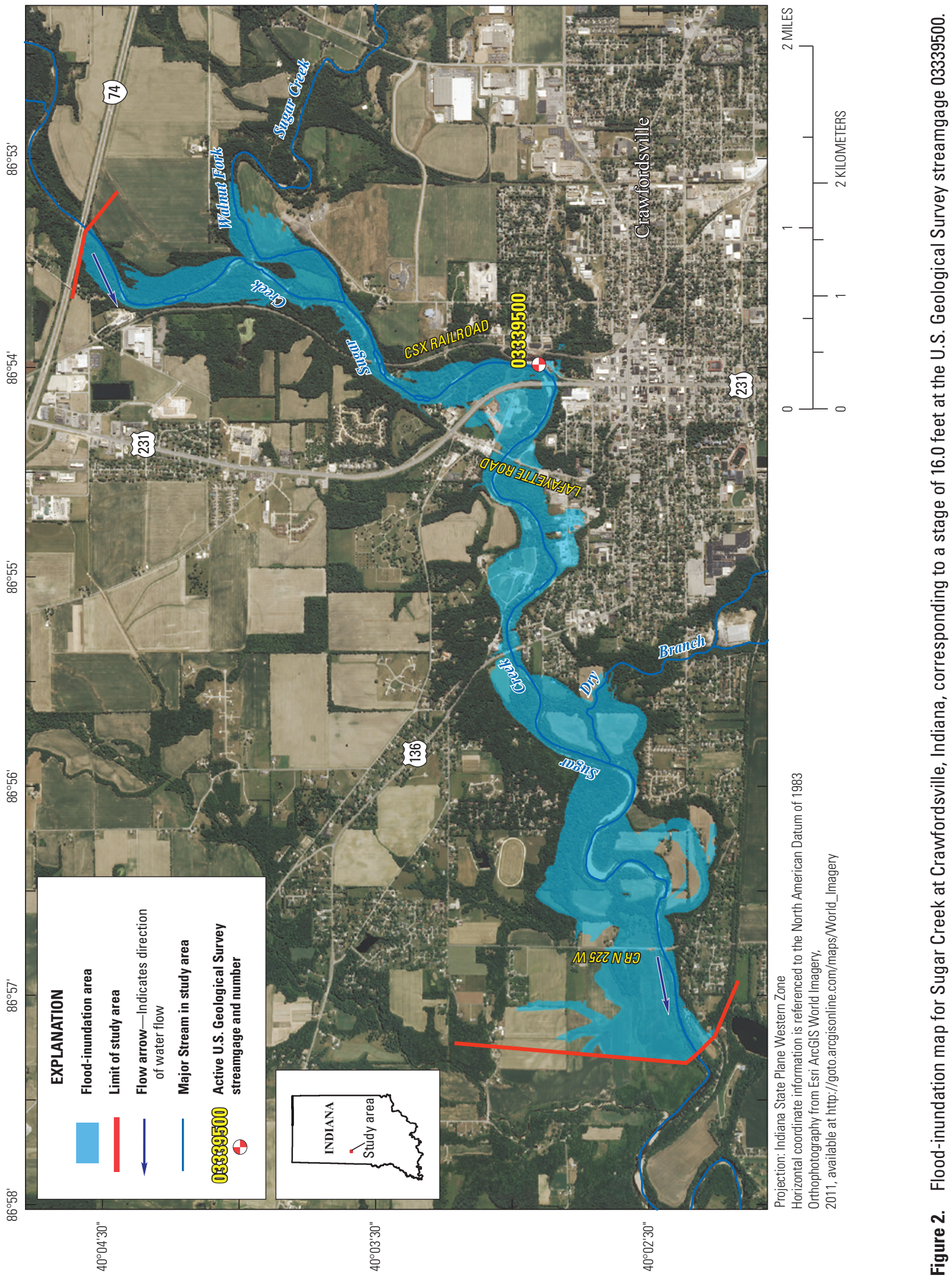
backwater into major tributaries along a main stem river, backwater from localized debris or ice jams, or backwater into storm sewers and detention basins. The accuracy of the floodwater extent portrayed on these maps will vary with the accuracy of the digital elevation model used to simulate the land surface.

If this series of flood-inundation maps will be used in conjunction with National Weather Service (NWS) river forecasts, the user should be aware of additional uncertainties that may be inherent or factored into NWS forecast procedures. The NWS uses forecast models to estimate the quantity and timing of water flowing through selected stream reaches in the United States. These forecast models (1) estimate the amount of runoff generated by precipitation and snowmelt, (2) simulate the movement of floodwater as it proceeds downstream, and (3) predict the flow and stage (and water-surface elevation) for the stream at a given location (AHPS forecast point) throughout the forecast period (every 6 hours and 3 to 5 days out in many locations). For more information on AHPS forecasts, please see: http://water.weather.gov/ahps/pcpn_and_ river forecasting.pdf.

An additional source of uncertainty is the active rating curve, 20.1, at USGS streamgage 03339500, Sugar Creek at Crawfordsville, Ind. The upper end of the rating curve has been extrapolated to double the highest direct discharge measurement, which is the suggested limit in USGS rating development (Rantz, 1982). However, the high-water marks for the April 19, 2013, flood, with a stage of $15.3 \mathrm{ft}$, verified the hydraulic model throughout the reach. Other sources of uncertainty are the model discharges and water-surface elevations on Sugar Creek upstream of Walnut Fork Sugar Creek. The drainage area on Sugar Creek decreases approximately 18 percent upstream of Walnut Fork Sugar Creek and the streamgage. Thus, there is some uncertainty in the discharge that Walnut Fork Sugar Creek outputs and Sugar Creek contains during each flood event in the upper reach of the hydraulic model. Additional uncertainties and limitations pertinent to this study may be described elsewhere in this report.

\section{Summary}

A series of 13 digital flood-inundation maps were developed in cooperation with the Indiana Office of Community and Rural Affairs for USGS streamgage 03339500, Sugar Creek at Crawfordsville, Ind. The maps cover a reach about 6.5 miles (mi) long from U.S. Interstate 74 to approximately $0.5 \mathrm{mi}$ downstream of County Road N225W near Crawfordsville. The maps were developed by using the U.S. Army Corps of Engineers' HEC-RAS and HECGeoRAS programs to compute water-surface profiles and to delineate estimated flood-inundation areas and depths of flooding for selected stream stages. The HEC-RAS hydraulic model was calibrated to the current stage-discharge relation at USGS streamgage 03339500, Sugar Creek at Crawfordsville,
Ind., and to the flood of April 19, 2013. The model was used to compute 13 water-surface profiles for flood stages at $1-\mathrm{ft}$ intervals referenced to the streamgage datum and ranging from $4.0 \mathrm{ft}$ or the National Weather Service "action stage" to $16.0 \mathrm{ft}$, which is the highest stage interval of the current USGS stage-discharge rating curve and $2 \mathrm{ft}$ higher than the National Weather Service "major flood stage." The simulated water-surface profiles were then combined with a Geographic Information System digital elevation model derived from light detection and ranging data to delineate estimated floodinundation areas as shapefile polygons and depth grids for each profile. These flood-inundation polygons were overlaid on high-resolution, georeferenced aerial photographs of the study area. The flood maps are available through a mapping application that can be accessed on the USGS Flood Inundation Mapping Science Web site (http://water.usgs.gov/ osw/flood_inundation).

Interactive use of the maps on this mapping application can give users a general indication of depth of water at any point by using the mouse cursor to click within the shaded areas. These maps, in conjunction with the real-time stage data from USGS streamgage 03339500, Sugar Creek at Crawfordsville, Ind., and forecasted flood stage data from the National Weather Service Advanced Hydrologic Prediction Service will help to guide the general public in taking individual safety precautions and will provide emergency management personnel with a tool to efficiently manage emergency flood operations and post-flood recovery efforts.

\section{References Cited}

Dewberry, 2012, National Enhanced Elevation Assessment: Fairfax, Va., 84 p., accessed July 2013, at http://www. dewberry.com/docs/default-source/documents/neea_finalreport_revised-3-29-12.pdf?sfvrsn=0.

Esri, 2015, ArcGIS, accessed July 2015, at http://www.esri. com/software/arcgis/.

Federal Emergency Management Agency, 2012, Flood Insurance Study, Montgomery County, Indiana, and incorporated areas: Washington D.C., 38 p.

Gray, H.H., 2000, Physiographic divisions of Indiana: Bloomington, Ind., Indiana Geological Survey Special Report 61, $15 \mathrm{p} ., 1 \mathrm{pl}$.

Indiana Department of Natural Resources, 2014, Coordinated discharges of selected streams in Indiana, accessed January 2014, at http://www.in.gov/dnr/water/4898.htm.

Indiana University, 2013, Indiana spatial data portal, accessed March 2014, at http://gis.iu.edu/. 
Merwade, V., 2011, Creating bathymetry mesh from cross sections: Purdue University, School of Civil Engineering, accessed March 2013, at http://web.ics.purdue. edu/ vmerwade/research/bathymetry_tutorial.pdf.

Merwade, V., Cook, A., and Coonrod, J., 2008, GIS techniques for creating river terrain models for hydrodynamic modeling and flood inundation mapping: Environmental Modeling and Software, v. 23, p. 1300-1311.

National Weather Service, 2015a, Advanced Hydrologic Prediction Service, Sugar Creek at Crawfordsville, accessed April 2015, at http://water.weather.gov/ahps2/hydrograph. php? wfo $=$ ind \&gage $=$ CRWI3 .

National Weather Service, 2015b, National Weather Service Glossary, accessed April 2015, at http:/w1.weather.gov/ glossary/.

Phillips, J.V., and Tadayon, S., 2006, Selection of Manning's roughness coefficient for natural and constructed vegetated and non-vegetated channels, and vegetation maintenance plan guidelines for vegetated channels in central Arizona: U.S. Geological Survey Scientific Investigations Report 2006-5108, 41 p.

Rantz, S.E., and others, 1982, Measurement and computation of streamflow: Volume 2, Computation of discharge: U.S. Geological Survey Water-Supply Paper 2175, 373 p.

U.S. Army Corps of Engineers, Hydrologic Engineering Center, 2010a, HEC-RAS River Analysis System, Hydraulic Reference Manual, version 4.1 [variously paged].

U.S. Army Corps of Engineers, Hydrologic Engineering Center, 2010b, HEC-RAS River Analysis System, User's Manual, version 4.1 [variously paged].
U.S. Army Corps of Engineers, Hydrologic Engineering Center, 2011, HEC-GeoRAS, GIS Tools for Support of HEC-RAS using ArcGIS, User's Manual, version 4.3.93 [variously paged].

U.S. Army Corps of Engineers, Louisville District, undated, Flood Plain Information (Floodway Delineation) Sugar Creek, Crawfordsville, Indiana.

U.S. Census Bureau, 2010, 2010 Census interactive population search IN-Crawfordsville town: Washington, D.C., accessed May 2015, at http://www.census.gov/2010census/ popmap/ipmtext.php?fl=18.

U.S. Geological Survey, 2015a, USGS 03339500, Sugar Creek at Crawfordsville, Indiana: U.S. Geological Survey, accessed April 2015, at http://waterdata.usgs.gov/in/nwis/ uv?site_no $=03339500$.

U.S. Geological Survey, 2015b, USGS surface-water data for the Nation: U.S. Geological Survey, accessed April 2015, at http://waterdata.usgs.gov/nwis/sw.

U.S. Geological Survey, 2015c, USGS Flood Inundation Mapping Science: U.S. Geological Survey, accessed July 2015, at http://water.usgs.gov/osw/flood_inundation.

U.S. Geological Survey, 2015d, StreamStats for Indiana streams, accessed April 2015, at http://streamstats.usgs.gov/ indiana.html.

Woolpert, Inc., 2011, Woolpert Order No. 71177, Indiana Statewide Imagery and LiDAR Program, remote sensing image: Dayton, Ohio, Woolpert, Inc., metadata available at http://gis.iu.edu/files/documents/in2011_ortho.txt. 

Publishing support by:

The Pembroke and Madison Publishing Service Centers 


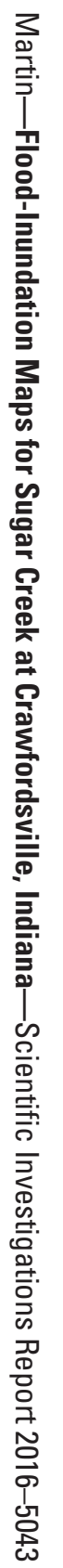

